\title{
Women Entrepreneurship Development in Yemen: The Role of Decision-Making Empowerment
}

\author{
Abeer Al-Radami ${ }^{1}$, Mohammed Saleh Al-Abed ${ }^{2}$ \\ ${ }^{1}$ Open University Malaysia, Kuala Lumpur, Malaysia \\ ${ }^{2}$ Impact Research Center, Sana'a, Yemen \\ Correspondence: Abeer Al-Radami, Open University Malaysia, Malaysia. roua2012@gmail.com \\ Received: August 31, 2021 Accepted: September 8, 2021 Online Published: September 10, 2021 \\ doi:10.48110/joi.v2i2.41 \\ URL: https://doi.org/10.48110/joi.v2i2.41
}

\begin{abstract}
This research was conducted to examine the impact of decision-making empowerment on women entrepreneurship development in Yemen. Two dimensions of decision-making empowerment were used; economic decision making, and household decision-making empowerment. This study employed the quantitative approach and the method of collecting data was the online-questionnaire. The targeted sample size of this study was 200 business women in Yemen and the response rate was 96.5\%. The results of the correlational analysis show that there is a clear strong positive correlation between decision-making empowerment and women entrepreneurship development. In addition, the two dimensions; economic decision making, and household decision-making have a significant relationship with women entrepreneurship development. The results of the regression analysis reveal that decision-making empowerment has a significant impact on women entrepreneurship development and the economic decision-making empowerment and household decision-making empowerment were explaining women entrepreneurship development. It can be concluded that empowering women by allowing them to participate in economic and household decision-making appears to be one of the important factors for developing women's entrepreneurship in particular, which in turn will help reduce poverty as well as achieve economic growth.
\end{abstract}

Keywords: Women, Empowerment, Entrepreneurship, Decision-Making, Yemen

\section{Introduction}

Entrepreneurship has traditionally been defined as the process of designing, launching and running a new business, which typically begins as a small business, such as a startup company, offering a product, process or service for sale or hire, and the people who do so are called 'entrepreneurs' (Burns, 2010). On the other hand, women entrepreneurship means an act of business ownership and business creation that empowers women economically increases their economic strength as well as position in society (Rani, 1996).

According to Rani (1996), women entrepreneurs have been making a considerable impact in almost all segments of the economy. About half of the world's population is made up of women. Most of them are unemployed. The global economy struggles greatly as a result of women's unequal opportunities at work. This is also the reason for the delay in developing countries. Therefore, the concept of "women empowerment" appears and becomes one of the vital development issues and it has a relationship with women entrepreneurship.

Women empowerment, according to Nussbaum (2001), refers to increasing and enhancing women's social, physical, political, and legal authority, ensuring equal justice for women, and giving them the confidence to assert their rights. The roots of the concept of empowerment appeared on the 60s, associated with social movements which care about civil and social rights of citizens, and has since used the concept of empowerment in several meanings, as well as used in several areas; such as economics, social and political work, as well as in development (Swift \& Levin, 1987).

There are many of articles and theories on empowerment of women which is associated with different factors. The way these variables are classified differs from one author to the next. For instance, Pandey and Singh (2008) studied women empowerment and personal values as predictors of reproductive health. In their study, findings evinced a compatible relationship between empowerment, personal values and reproductive health. Moreover, employment level and high personal values exercise impact on better reproductive health status. 
In another research, Afrin, Islam, and Ahmed (2008) developed a multivariate model of micro-credit and rural women's entrepreneurship growth. Their research perceived that the micro credit program helps to develop socioeconomic status of the rural women in Bangladesh. The research's significant result is that borrowers' financial management skills and the group identity of the borrowers have a clear and significant association with the growth of rural women entrepreneurship through micro-credit programs. Past studies into personal dissatisfaction (a motivational factor) concluded that personal dissatisfaction as a 'push factor' with an inherent impact on women entrepreneurs' success will aid in solving the difficulties they face in industry, shedding more light on the various effects of each of the motivational variables on women entrepreneurial challenges.

In addition, Singh, Simpson, Mordi, and Okafor, (2011) examined the relationship between entrepreneurial motivations factors and women entrepreneurial challenges. They concluded that personal satisfaction as a 'push factor' with an inherent impact on women entrepreneurs' success will aid in solving the difficulties they face in the industry, shedding more light on the various effects of each of the motivational variables on women entrepreneurial challenges.

According to SFD (2019), more than 800 thousand clients, $38 \%$ of them are women, receive financial services through 10 microfinance institutions spread over 150 branches in Yemen. The participation of women in economic activities occupied a prominent place in the list of strategic priorities and national development plans in the Yemen. The proportion of female microfinance borrowers had declined from 54\% in 2014 to $41 \%$ in 2018. (SFD, 2019).

From reviewing previous literature, the author is not aware of any study that attempts to examine the relationship between decision-making empowerment and women entrepreneurship development, and particularly, there is no study attempt to examine the impact of decision-making empowerment with the dimensions: (1) Economic decision-making empowerment, (2) household decision-making empowerment; on women entrepreneurship development with the dimensions: (1) Independence, (2) Ability to make complex decision, (3) Ability to seek and grasp opportunity, (4) Ability to take risk and initiative; in Yemen.

Accordingly, it is necessary to conduct such research for increasing the awareness of women entrepreneurship development, especially in one of the Middle Eastern countries; such as Yemen. Hence, this study attempts to examine the impact of decision-making empowerment on women entrepreneurship development in Yemen. It aims to answer the following main question.

- Does decision-making empowerment have a significant impact on women entrepreneurship development in Yemen?

In addition, this study aims to answer the following sub-questions:

- Does economic decision-making empowerment have a significant impact on women entrepreneurship development in Yemen?

- Does household decision-making empowerment have a significant impact on women entrepreneurship development in Yemen?

\section{Literature Review}

\subsection{Women Entrepreneurship Development}

According to Katz and Gartner (1988), the concept of entrepreneurship is the creation of a new business. Entrepreneurship development is designed to help an individual in strengthening his entrepreneurial, motive and in acquiring skills and capabilities necessary for playing his entrepreneurial role effectively (Boyd \&Vozikis ,1994).

The growth of the rate of women entrepreneurs in developing countries has drawn the attention of both the academic and the development sectors. International public institutions, national and local Governments, NGOs, private companies, charities, knowledge institutes and business associations have initiated programs or policies to promote and develop women's entrepreneurship.

In recent years, the attention to women and entrepreneurship in developing countries has increased to a great extent and the focus on this 'untapped source' of growth seem to be indispensable nowadays for development practitioners and policy makers. According to Ariffin, Baqutayan and Mahdzir (2020), the question of how to support and enhance the development of women entrepreneurship is of primary concern to policy makers, so discussions of the importance of entrepreneurship in developing countries focus on this issue in particular. It is noticeable that there are distinguished efforts that focus on supporting women's economic empowerment as a fundamental pillar in sustainable development. However, despite this growing number of initiatives and resources 
made available to enhance and develop women's entrepreneurship in developing countries, women still own and manage fewer businesses than men (Sharma, 2015).

A study by Abdo and Kerbage (2012) identified the restrictions facing women entrepreneurs in Lebanon in starting and expanding their businesses. It reveals different approaches adopted by Women Entrepreneurship Development (WED) to support organizations, analyses the structural gaps that characterize WED initiatives, and makes recommendations which purpose to make it more possible for women to achieve sustainable enterprise development in Lebanon.

Afrin et al. (2008) proposed a multivariate model of micro credit and rural women entrepreneurship development in Bangladesh. They explained five dimensions that are: innovation, independence, ability to make complex decisions, ability to seek and grasp opportunities, and ability to take risks and initiative for women entrepreneurship development in Bangladesh. Their study found that the financial management skill and the group identity of the borrowers have a direct and significant relationship with the development of rural women entrepreneurship development through micro credit programs. The significant relationships indicate that if the micro credit borrowers can enhance this skill among the rural women borrowers, it would lead them towards the development of entrepreneurship.

In this study, the four dimensions studied by Afrin et al. (2008); independence, ability to make complex decisions, ability to seek and grasp opportunities, and ability to take risks and initiative; were used for the purpose of measuring women entrepreneurship development.

\subsubsection{Independence}

The word "independence" refers to someone or something that is free of another's power or control (Moore, 1973). Furthermore, independence can be described as someone or something that is not affected by external factors such as opinions or regulations (Healy \& Palepu, 2001).

The need for independence is a psychological trait that many empirical studies offer as a characteristic of entrepreneurs or a driver that enhances entrepreneurship (Low \& MacMillan, 1988). Koh (1996) found that entrepreneurial inclination is significantly associated with some psychological characteristics; Although not statistically significant, descriptive statistics suggest that the entrepreneurially inclined also possess a higher need for achievement, greater (internal) locus of control and more self-confidence.

In their study, Smeaton, Ray and Knight (2015) stated that if you have the independence to make your own decisions, it is considered the key benefit of being an entrepreneur. Nearly $90 \%$ of respondents said decisionmaking independence was very remarkable, closely followed by more flexibility for a greater work/life balance.

\subsubsection{Ability to Make Complex Decisions}

According to Fülöp (2005), Decision making is the method of separating choices based on the values and interests of the individual making the decision. Making a decision implies that there are alternatives to consider, and in this case, we don't need to accept as many as possible, but rather choose the one that best suits our goals, aims, needs, beliefs, and so on. Problem-solving often requires making decisions, and decision-making is particularly critical in management and leadership (Saaty, 1990).

Saaty (1990) clarified the current circumstance and developments as respects women's and men's participation in political, financial and social decision-making within the period from 2003 to 2014. The study aimed to highlight the gender gaps in administration positions and to distinguish zones of decision-making where eminent advance was made. As a result, the study found that women's representation on corporate boards has improved the most. Women's participation in political decision-making is slowly increasing, and from 2003 to 2014, women held more than $30 \%$ of decision-making positions in the European Parliament and European Commission.

\subsubsection{Ability to Seek and Grasp Opportunities}

An opportunity is anything that provides you with a chance to change your circumstances for the better (Hammond, Keeney \& Raiffa, 2015). Opportunity identification and selecting the right opportunity for business is one of the important abilities of a successful entrepreneur (Ardichvili, Cardozo \& Ray, 2003).

$\mathrm{Li}$, Chen, Liu and Peng (2014) examined the effect of managerial ties on opportunity capture from a social capital perspective. After they drew on a sample of 159 new ventures, they found that ties with other firms have a stronger positive effect on opportunity capture than ties with government. They also found that organizational learning moderates the relationship between managerial ties and opportunity capture. 
One of the significant skills of a successful entrepreneur, is the ability to identify opportunities and selecting the right opportunity for his/her business. Therefore, one cannot speak about opportunity without speaking about entrepreneurship because entrepreneurship is more than just a business start-up, it is an individual's ability to seize opportunities and turn ideas into action.

Hagar (2015) explained the entrepreneur opportunity identification in Finland. The main aim of this study was first, to produce information that may guide a prospective entrepreneur to recognize and evaluate business opportunity, second, to better understand market situation, third, to realize the potential economic profit. The interview compared with the theory part that found out that an entrepreneur needs to be open to all the business opportunities because the opportunity may emerge even from areas which seem stagnant, trends and market situation change rapidly, so, business opportunity may emerge from these changes, and understanding past trends helps to somehow estimate future trends, even though future trends are hard to predict.

\subsubsection{Ability to Take Risks and Initiative}

Lumpkin and Dess (1996) seeked to know the importance of taking chances in the entrepreneurial environment, as well as the method of taking initiative. Initiative was described as the willingness to take constructive action. It's the polar opposite of reacting.

Companies pursuing market growth must be willing to take risks, which is the engine that drives business. Risks, on the other hand, are often viewed solely as threats, despite the fact that they can present substantial opportunities and possibilities for operational advancement and new competitive advantage, resulting in short- and long-term profitability (Bekefi, Epstein \& Yuthas, 2008). In the life of an entrepreneur, as well as in today's workplace, taking initiative has become increasingly important. Employees who can think on their feet and take action without waiting for orders are important for the entrepreneur. This kind of adaptability and bravery is what drives teams and companies to evolve, conquer competition, and achieve success, and it's also a very impressive personal attribute for an entrepreneur running their own company, both commercially and socially (Davis, 2002).

\subsection{Women Decision-Making Empowerment}

Cornwall (2016) defined empowerment as the process of challenging existing power relations and of winning greater control over the sources of power. While Kabeer (2005) defined empowerment as the process by which those who have been denied the ability to make strategic life choices obtain that ability. Women empowerment means to give official authority or legal power to women (Kabeer, 1999). Goetz and Sen Gupta (1994) defined women empowerment as the challenge to the prevailing power relations that goals to increase the control of the supplier and sources of power process. Women empowerment is to give her the right to ownership, to entrepreneurship and the right to work with freedom of movement by the government, society and household (Rowlands, 1997).

Today is the time when women empowerment is a must to give equal importance to them. Women empowerment can make a lot of difference to our society in a number of ways (Belenky et al., 1986). According to Sen and Batliwala (2000), empowering women is the process by which women gain greater control over their life circumstances. The participation of women in decision-making is one of the objective indicators of women's economic and social empowerment.

Previous studies discuss the empowerment of women from different aspects. Fulp (2014) examined the causal relationship between entrepreneurship and women empowerment in Ghana. He focused on how tailors and batikers working with Global Mamas experience empowerment, specifically autonomous decision-making and financial independence, and secondly, how effectively the two different types of employment models within Global Mamas programs are faced with the organization's mission of empowering women. The aims of this study were. First, to examine how the term empowerment is operationalized in the literature and meaningfully understood in practice and in the field, second, to separate the causal mechanism between business ownership and empowerment. However, this research filled the gap of designing specifically to ensure that the full range of causal directions was allowed for. As a result, owning a small business in Ghana does not lead the women to empowerment, rather, empowered women decide to open small businesses. The study found that there is still need for social justice, equality and human rights for women to develop women empowerment.

Dwivedi and Dwivedi (2011) studied women-empowerment through women entrepreneurship. They explained the contribution by female-entrepreneurs in the economic development of their nations and also sought to find out the current problems they face in their businesses. This study was conducted in the Faizabad zone of UttarPradesh. This study found that a home-based enterprise is appropriate for those women entrepreneurs who have 
problems going outside the home due to family responsibility or their culture. The women can start an enterprise inside their homes.

Mathew and Panchanatham (2011) discussed the skills and talents of the women entrepreneurs and the objectives of this study were to describe the women's empowerment by entrepreneurship, and to suggest the remedial measures to women entrepreneurs. As a result of this study, the growth of women is not only individual growth, but it is a growth of the family and of the country. The skills and talents that women entrepreneurs have in them is the empowerment of a country. The empowerment of the women is their nations' richness.

In another study, Duru (2011) focused on understanding men's interference in women's empowerment and NonGovernmental Organizations (NGOs) in Nigeria. She focused on the nature of patriarchy, male domination in decision making, culture and how they influence women development, empowerment, and complacency. She found that the society enables men to have dominance over women and ethnicity plays an important role in determining women's decision-making authority in Nigeria. This study showed that employed women felt more empowerment than unemployed women and that empowerment makes women more independent, confident and responsible.

Nessa, Ali and Abdul-Hakim (2012) examined the impact of a microcredit program on women empowerment in Bangladesh. They concluded that empowerment of poor women in Bangladesh can be significantly improved by encouraging them to participate in microcredit programs. Subbiah (2019) stated that for the purpose of bridging the gaps in gender inequality, women should be empowered by making them active partners in decision-making, implementation and evaluation of all initiated interventions in order to emerge, organize and sustain their livelihoods. According to him, empowerment is an ongoing process and not an end in itself.

Accordingly, this study developed the following main hypothesis.

\section{H1: Decision-making empowerment has a significant impact on women entrepreneurship development.}

In this study, women decision-making empowerment was measured by using two dimensions adapted from Nessa et al. (2012); economic decision-making, and household decision-making empowerment. These dimensions are discussed in the following sub-sections.

\subsubsection{Economic Decision-Making Empowerment}

There has been a growing interest in the issues of women's participation globally, regionally and locally because it is certain that no society can promote development without the participation of women in the process of sustainable development (Sontheimer, 1991). The experience of many countries has shown that combating women's poverty and economic empowerment leads to the well-being of society as a whole. Increasing women's income leads to an increase in household expenditure on health, education and nutrition, leading to an increase in men's income and thus increasing human capital, as well as the return of women's education to the fertility rate, nutrition and health of children (Cheston \& Kuhn, 2002). Women's participation in development and empowerment of them is one of the indicators upon which the progress and advancement of nations are measured, and important indicators in the ranking of countries in various human development guides (Moghadam \& Senftova, 2005).

Economic empowerment is to create a financial and non-financial package that helps women find their own sources of income. As a result, the process of empowering women has become a series of overlapping episodes that start first from stimulating, raising awareness, and training them to find their own source of income that often through small enterprises (Jitha, 2013). Second, by helping them to find the necessary funding for these enterprises. Third, the most important goal of empowerment is enabling women to run their enterprises with an economic return and create additional income for these women and their families (McKee, 1989).

The economic contribution of women is of great importance because it represents half of human resources, which is an important factor in achieving economic development in the various economic sectors. Increasing women's participation in economic activities will lead to higher economic growth rates and will create new jobs (Boserup \& Kanji, 2007).

Economic empowerment has been studied by scholars in different ways. The study found that the efforts to help women empower themselves through vocational training, employment opportunities and social groups need to consider the potential unintended consequences for these women. Sabri (2015) explained the social aspects of female entrepreneurship and explored the contributions of female entrepreneurship to social transformation in terms of economic and cultural practices. This study found that female entrepreneurship in the formal economy of Afghanistan is a new phenomenon because of the limited size and scope of their enterprises. Norms and a 
patriarchal society prompt negative views about women's presence in business. Accordingly, this study developed the following sub-hypothesis.

\section{H1a: Economic decision-making empowerment has a significant impact on women entrepreneurship development.}

\subsubsection{Household Decision-Making Empowerment}

Household decision making empowerment means how the household acceptance of women's participation in household decision making is an indicator of empowerment (Kabeer, 1999). The family is not only the foundation of the existence of society, but also the source of morality and the foundation for control of behavior and motivating family members to succeed in all areas. Household sharing in different types of decisions and whether all types of sharing is equal to empowerment. All of these decisions are related to women in all countries and cultures (Curtis, 1986).

A study by Kishor and Subaiya (2005) identified household decision making as empowerment. They discussed the different meanings of decision making across countries. They concluded that the pattern of participation in decision making varies greatly across countries and within country, across decisions. In most countries, the decisions most commonly made alone are about health care and small household purchases. Even though only currently married women were included in the analysis, joint decision making is not the norm and is most common for decision making about visits to friends and family.

In addition, Kishor, and Subaiya (2005) revealed that women in Benin and Kenya are the ones who are most likely to not participate in any decision at all. This is particularly surprising given the much higher rates of employment for cash in these countries. The variance in participation is also not explained by other characteristics such as education. In fact, when a simple count of women's participation is regressed on hypothesized correlates of empowerment such as education and working for cash, the R-square never exceeds 0.18 in any country and tends to be highest for the regression explaining women's number of decisions taken alone. Accordingly, this study developed the following sub-hypothesis.

\section{H1b: Household decision-making empowerment has a significant impact on women entrepreneurship development.}

\section{Methods}

The quantitative approach was used in this study and the online questionnaire was used as the key instrument to obtain the necessary data. The questionnaire of this study consists of three parts. The first part provides instructions for the respondents, while the second part includes the demographic information. The third part of the questionnaire presents the measurements of the main variables. Sixteen items were adapted from different studies; Wiklander (2010), Nmark (1993), Graflund (2013), Pitt et al. (2006), Andrews et al. (2013), Robinson et al. (2013), and Grasmuck and Espinal (2000); for the purpose of measuring decision-making empowerment and its dimensions. In addition, seventeen items were adapted for measuring women entrepreneurship development and its dimensions from Goheer (2003), Robinson et al. (2013), and Kennedy (2002). 5-Likert scale was used for all items in measuring decision-making empowerment and women entrepreneurship development (1: strongly disagree, 2: disagree, 3: neutral, 4: agree, and 5: strongly agree).

Cronbach's Alpha was used in order to test the scale reliability in this study. Table 1 shows that all variables with dimensions are reliable and the values of Cronbach's alpha are $>0.7$. In addition, correlation analysis was used to measure the validity of the instrument, and the results show that there is a statistically significant correlation between the overall main of the study variables and its items, which indicates that the variables explain enough variance in its items. Accordingly, the instrument has a good validity.

Table 1. Cronbach's Alpha

\begin{tabular}{lll}
\hline Variable & $\begin{array}{l}\text { N of } \\
\text { Items }\end{array}$ & $\begin{array}{l}\text { Cronbach's } \\
\text { Alpha }\end{array}$ \\
\hline Economic decision-making & 8 & .859 \\
Household decision-making & 8 & .879 \\
Women Entrepreneurship & 17 & .953 \\
All items & 33 & .962 \\
\hline
\end{tabular}


This study targeted the Yemeni business women and according to the statistics published by Women's News Agency (2013), the total number of Yemeni business women are 400. According to the sample size table proposed by Krejcie and Morgan (1970), the sample size of 400 (the targeted population of this study) was 196 business women and the sample random method was used in order to select the participants.

\section{Findings}

The questionnaire was distributed to 200 business women by sharing the link of the questionnaire online at What's App. A total of 193 questionnaires were collected back and were valid for the test since all questions were completely filled. In other words, $96.5 \%$ (response rate) of distributed questionnaires were returned and valid for the research analysis. Frequency analysis was performed to analyze the demographic data and the research reveals that $87.6 \%$ of the business women have businesses in Sana'a, and $12.4 \%$ of the business women have businesses in different cities; Ibb, Taiz, Aden, and Hudaidah.

The respondent's age distribution was $47 \%$ of the business women are under 30 years old, and the same percentage for the business women who are between 30 and 40 years old. Only $4 \%$ of the business women who are between 41 and 50 years old, and only $3 \%$ who are over 50 years old. The result of education distribution shows that $67 \%$ of the respondents have a university degree, $18 \%$ have a secondary education, $8 \%$ have a master degree, $5 \%$ have elementary and basic education, and only $2 \%$ have a $\mathrm{PhD}$ degree.

Regarding to the experience, $47 \%$ of the respondents have experience for less than 2 years, $27 \%$ have between 2 5 years of experience, and only $13 \%$ have between 6-10 years of experience, and $13 \%$ have over 10 years of experience. Referring to the children, $45 \%$ of the business women have children, while $55 \%$ of them don't have children.

Descriptive statistics includes the means and standard deviations for the variables (Women Entrepreneurship as dependent variable whereas decision-making empowerment is an independent variable with its dimensions; economic decision-making empowerment, and household decision-making empowerment). All the variables are evaluated based on a 5-point scale. Table 2 shows a summary of the descriptive statistics of all variables which indicates that seventeen items used to measure the women entrepreneurship development have a mean of 4.17 (Agree) with standard deviation of 0.57 , eight items used to measure the economic decision-making have a mean of 3.32 (Neutral) with standard deviation of 0.84 , and eight items used to measure the household decision-making have a mean of 3.31 (Neutral) with standard deviation of 0.85 .

Table 2. Summary of the Descriptive Statistics

\begin{tabular}{llll}
\hline & Mean & Std. Deviation & Verbal Result \\
\hline Economic decision making & 3.32 & 0.84 & Neutral \\
Household decision making & 3.31 & 0.85 & Neutral \\
Women Entrepreneurship & 4.17 & 0.57 & Agree \\
\hline
\end{tabular}

Table 3 shows the descriptive statistics of economic decision making, where the (Q6) paragraph (I think women empowerment lead to the family being better of economically) got the first rank with a mean of 3.927 (Agree), and standard deviation of (1.17). The (Q4) paragraph (I have never been prevented from working outside the home even if I wanted to) ranked last with a mean of 2.00 (Disagree) and standard deviation of (1.09). The overall average of the variable is 3.32 (Neutral) and the standard deviation is (0.84).

Table 3. The Descriptive Statistics of Economic Decision Making

\begin{tabular}{|c|c|c|c|c|}
\hline Rank & Item & Mean & $\begin{array}{l}\text { Std. } \\
\text { Deviation }\end{array}$ & $\begin{array}{l}\text { Verbal } \\
\text { Result }\end{array}$ \\
\hline 1 & $\begin{array}{l}\text { Q6. I think women's empowerment lead to the family being better } \\
\text { of economically }\end{array}$ & 3.927 & 1.1659 & Agree \\
\hline 2 & Q7. I think empowering women economically reduction poverty & 3.886 & 1.1759 & Agree \\
\hline 3 & $\begin{array}{l}\text { Q5. I think women should have the right to access to networks, } \\
\text { mentorship and coaching }\end{array}$ & 3.487 & 1.1416 & Agree \\
\hline 4 & $\begin{array}{l}\text { Q1. I feel comfortable giving my opinion in the presence of my } \\
\text { husband or other family member }\end{array}$ & 3.425 & 1.1300 & Agree \\
\hline 5 & Q2. I have an opinion in whether I should work outside the home & 3.347 & 1.1267 & Agree \\
\hline
\end{tabular}




\begin{tabular}{lllll}
\hline Rank & Item & Mean & $\begin{array}{l}\text { Std. } \\
\text { Deviation }\end{array}$ & $\begin{array}{l}\text { Verbal } \\
\text { Result }\end{array}$ \\
\hline $\mathbf{6}$ & Q3. I think women and men should get equal pay for equal work & 3.332 & 1.3165 & Neutral \\
$\mathbf{7}$ & Q8. I think women business should have a personal bank account & 3.155 & 1.3057 & Neutral \\
$\mathbf{8}$ & $\begin{array}{l}\text { Q4. I have never been prevented from working outside the home } \\
\text { even if I wanted to }\end{array}$ & 2.000 & 1.0897 & Disagree \\
& Economic decision making & $\mathbf{3 . 3 2}$ & $\mathbf{0 . 8 4}$ & Neutral \\
\hline
\end{tabular}

Regarding to the descriptive statistics of the items of household decision making, Table 4 shows that the (Q4) paragraph (I think women should have an opinion in whether to purchase major goods for the household such as a TV) got the first rank with a mean of 3.772 (Agree), and standard deviation of (1.20). The (Q2) paragraph (I think a man should make decisions and a woman should obey) ranked last with a mean of 1.81 (Disagree) and standard deviation of (1.00). The overall mean of the variable is 3.31 (Neutral) and the standard deviation is (0.85).

Table 4. The Descriptive Statistics of Household Decision Making

\begin{tabular}{|c|c|c|c|c|}
\hline Rank & Item & Mean & $\begin{array}{l}\text { Std. } \\
\text { Deviation }\end{array}$ & $\begin{array}{l}\text { Verbal } \\
\text { Result }\end{array}$ \\
\hline 1 & $\begin{array}{l}\text { Q4. I think women should have an opinion in whether to purchase } \\
\text { major goods for the household such as a TV }\end{array}$ & 3.772 & 1.2032 & Agree \\
\hline 2 & $\begin{array}{l}\text { Q7. I think my family should encourage me to become an } \\
\text { entrepreneur }\end{array}$ & 3.627 & 1.2648 & Agree \\
\hline 3 & $\begin{array}{l}\text { Q3. I think women should have a role in the decision making of } \\
\text { household expenditure }\end{array}$ & 3.565 & 1.1977 & Agree \\
\hline 4 & $\begin{array}{l}\text { Q5. I think women should have any opinion in how the household's } \\
\text { overall income is spent }\end{array}$ & 3.554 & 1.1719 & Agree \\
\hline 5 & $\begin{array}{l}\text { Q6. I think wife should have an opinion in how many children to } \\
\text { have }\end{array}$ & 3.534 & 1.1859 & Agree \\
\hline 6 & $\begin{array}{l}\text { Q8. I think I have the opportunity to balance work and family } \\
\text { demands }\end{array}$ & 3.446 & 1.0648 & Agree \\
\hline 7 & $\begin{array}{l}\text { Q1. If I wanted to buy myself a dress, I feel free to do so without } \\
\text { taking counsel from my husband or a senior member of my family }\end{array}$ & 3.202 & 1.1706 & Neutral \\
\hline \multirow[t]{2}{*}{8} & Q2. I think a man should make decisions and a woman should obey & 1.813 & 1.0033 & Disagree \\
\hline & Household decision making & 3.31 & 0.85 & Neutral \\
\hline
\end{tabular}

Seventeen questions were used in order to measure women entrepreneurship development and Table 5 shows that the (Q6) paragraph (I feel with self-confident when I do my work) got the first rank with a mean of 4.534 (Strongly Agree), and standard deviation of (0.757). The (Q2) paragraph (I think government support for women entrepreneurs is increasing) ranked last with a mean of 3.845 (Agree) and standard deviation of (0.928). This proves that women entrepreneurs are not supported by the Government. The overall mean of this variable is 4.17 (Agree) and the standard deviation is (0.569).

Table 5. The Descriptive Statistics of Women Entrepreneurship Development

\begin{tabular}{llccl}
\hline Rank & Item & Mean & $\begin{array}{l}\text { Std. } \\
\text { Deviation }\end{array}$ & $\begin{array}{l}\text { Verbal } \\
\text { Result }\end{array}$ \\
\hline $\mathbf{1}$ & Q6. I feel with self-confident when I do my work & 4.534 & .7570 & $\begin{array}{l}\text { Strongly } \\
\text { Agree } \\
\text { Strongly } \\
\text { Agree } \\
\text { Strongly } \\
\text { Agree }\end{array}$ \\
& Q7. I think women should have her own savings & 4.508 & .7577 & $\begin{array}{l}\text { Agling } \\
\text { Strongly } \\
\text { Agree }\end{array}$ \\
\hline
\end{tabular}




\begin{tabular}{|c|c|c|c|c|}
\hline Rank & Item & Mean & $\begin{array}{l}\text { Std. } \\
\text { Deviation }\end{array}$ & $\begin{array}{l}\text { Verbal } \\
\text { Result }\end{array}$ \\
\hline 5 & $\begin{array}{l}\text { Q4. I think that women entrepreneurs are getting more technical } \\
\text { skills }\end{array}$ & 4.321 & .8039 & $\begin{array}{l}\text { Strongly } \\
\text { Agree }\end{array}$ \\
\hline 6 & $\begin{array}{l}\text { Q13. I think I am able to convert an opportunity into a workable } \\
\text { and marketable business }\end{array}$ & 4.238 & .6886 & $\begin{array}{l}\text { Strongly } \\
\text { Agree }\end{array}$ \\
\hline 7 & $\begin{array}{l}\text { Q12. I think I am able to select an opportunity in a short period of } \\
\text { time }\end{array}$ & 4.187 & .7475 & Agree \\
\hline 8 & Q3. I think that the market for women entrepreneurs is expanding & 4.130 & .8347 & Agree \\
\hline 9 & Q8. I have planning skills & 4.124 & .7396 & Agree \\
\hline 10 & Q9. I have organizing skills & 4.104 & .7142 & Agree \\
\hline 11 & $\begin{array}{l}\text { Q16. I think I can flexibly adapt to changing circumstances and } \\
\text { competitors }\end{array}$ & 4.078 & .6840 & Agree \\
\hline 12 & Q10. I have money management skills & 4.057 & .6470 & Agree \\
\hline 13 & $\begin{array}{l}\text { Q15. I think I have ability to accommodate to uncertainty and } \\
\text { ambiguity }\end{array}$ & 4.005 & .6495 & Agree \\
\hline 14 & $\begin{array}{l}\text { Q5. I think that access to finance and credit for women } \\
\text { entrepreneurs is increasing }\end{array}$ & 3.990 & .8477 & Agree \\
\hline 15 & $\begin{array}{l}\text { Q1. I think that the overall environment for women entrepreneurs } \\
\text { is good }\end{array}$ & 3.984 & .9041 & Agree \\
\hline 16 & $\begin{array}{l}\text { Q17. I think I can seek to evaluate and mitigate the risks of the } \\
\text { venture }\end{array}$ & 3.969 & .6685 & Agree \\
\hline \multirow[t]{2}{*}{17} & $\begin{array}{l}\text { Q2. I think government support for women entrepreneurs is } \\
\text { increasing }\end{array}$ & 3.845 & .9280 & Agree \\
\hline & Women Entrepreneurship & 4.17 & 0.57 & Agree \\
\hline
\end{tabular}

Independent samples t-test was used in order to compare the differences between sample response means of the women with and without children with regard to economic decision-making, household decision-making, and women entrepreneurship independently. According to the results, there is no significant difference in the extent of economic decision-making, household decision-making, and women entrepreneurship between women with children and women without children ( $p>0.05)$ as shown in Table 6.

Table 6. Independent Samples t-Test

\begin{tabular}{|c|c|c|c|c|c|c|c|c|}
\hline & & \multicolumn{7}{|c|}{ Levene's Test for Equality of Variances } \\
\hline & & F & Sig. & $\mathbf{t}$ & df & $\begin{array}{l}\text { Sig. (2- } \\
\text { tailed) }\end{array}$ & $\begin{array}{l}\text { Mean } \\
\text { Difference }\end{array}$ & $\begin{array}{l}\text { Std. Error } \\
\text { Difference }\end{array}$ \\
\hline $\begin{array}{l}\text { Economic } \\
\text { decision }\end{array}$ & $\begin{array}{l}\text { Equal variances assumed } \\
\text { Equal variances not }\end{array}$ & .464 & .496 & -.304 & 191 & .762 & -.037 & .122 \\
\hline making & assumed & & & -.305 & 185.57 & .760 & -.037 & .121 \\
\hline $\begin{array}{l}\text { Household } \\
\text { decision }\end{array}$ & $\begin{array}{l}\text { Equal variances assumed } \\
\text { Equal variances not }\end{array}$ & 3.460 & .064 & -.298 & 191 & .766 & -.037 & .124 \\
\hline making & assumed & & & -.293 & 166.90 & .770 & -.037 & .126 \\
\hline Women & Equal variances assumed & 2.830 & .094 & -.559 & 191 & .577 & -.04616 & .08254 \\
\hline Entrepreneurship & $\begin{array}{l}\text { Equal variances not } \\
\text { assumed }\end{array}$ & & & -.548 & 164.19 & .585 & -.04616 & .08426 \\
\hline
\end{tabular}

Analysis of Variance (ANOVA) was used to find out the significance differences between sample response means with regard with regard to entrepreneurship and strategic resource management according to the four age groups of respondents. Acoording to the results, there is no significant difference in the extent of economic decisionmaking, household decision-making, and women entrepreneurship between the four age groups of respondents ( $>0.05)$ as shown in Table 7. 
Table 7. ANOVA

\begin{tabular}{lllllll}
\hline & & Sum of Squares & df & Mean Square & F & Sig. \\
\hline Economic & Between Groups & 4.663 & 3 & 1.554 & 2.245 & .084 \\
Decision & Within Groups & 130.831 & 189 & .692 & & \\
Making & Total & 135.493 & 192 & & .405 & .750 \\
Household & Between Groups & .894 & 3 & .298 & & \\
Decision & Within Groups & 139.297 & 189 & .737 & & \\
Making & Total & 140.191 & 192 & & & .314 \\
Women & Between Groups & 1.154 & 3 & .385 & .323 & \\
Entrepreneurship & Within Groups & 60.986 & 189 & & & \\
& Total & 62.140 & 192 & & & \\
\hline
\end{tabular}

The relationship between decision-making empowerment with its dimensions; economic decision making and household decision making, and women entrepreneurship was examined by using Pearson Correlation as tabulated in Table 8. The results show that there is a clear strong positive correlation between decision-making empowerment and women entrepreneurship $(r=+0.838, \mathrm{p}=0.000)$. In addition, economic decision making has a significant relationship with women entrepreneurship $(\mathrm{r}=+0.791, \mathrm{p}=0.000)$. Furthermore, there is a significant relationship between household decision making and women entrepreneurship $(r=+0.817, p=0.000)$.

Table 8. Pearson Correlation Result

\begin{tabular}{|c|c|c|c|c|c|}
\hline & & $\begin{array}{l}\text { Decision } \\
\text { making } \\
\text { Empowerment }\end{array}$ & $\begin{array}{l}\text { Economic } \\
\text { Decision } \\
\text { Making } \\
\end{array}$ & $\begin{array}{l}\text { Household } \\
\text { Decision } \\
\text { Making }\end{array}$ & $\begin{array}{l}\text { Women } \\
\text { Entrepreneurship }\end{array}$ \\
\hline \multirow[t]{3}{*}{$\begin{array}{l}\text { Decision making } \\
\text { Empowerment }\end{array}$} & $\begin{array}{l}\text { Pearson } \\
\text { Correlation }\end{array}$ & 1 & $.959^{* *}$ & $.960^{* *}$ & $.838^{* *}$ \\
\hline & Sig. (2-tailed) & & .000 & .000 & .000 \\
\hline & $\mathrm{N}$ & 193 & 193 & 193 & 193 \\
\hline \multirow[t]{3}{*}{$\begin{array}{l}\text { Economic } \\
\text { Decision Making }\end{array}$} & $\begin{array}{l}\text { Pearson } \\
\text { Correlation }\end{array}$ & $.959^{* *}$ & 1 & $.842^{* *}$ & $.791^{* *}$ \\
\hline & Sig. (2-tailed) & .000 & & .000 & .000 \\
\hline & $\mathrm{N}$ & 193 & 193 & 193 & 193 \\
\hline \multirow[t]{3}{*}{$\begin{array}{l}\text { Household } \\
\text { Decision Making }\end{array}$} & $\begin{array}{l}\text { Pearson } \\
\text { Correlation }\end{array}$ & $.960^{* * *}$ & $.842^{* *}$ & 1 & $.817^{* *}$ \\
\hline & Sig. (2-tailed) & .000 & .000 & & .000 \\
\hline & $\mathrm{N}$ & 193 & 193 & 193 & 193 \\
\hline \multirow[t]{3}{*}{$\begin{array}{l}\text { Women } \\
\text { Entrepreneurship }\end{array}$} & $\begin{array}{l}\text { Pearson } \\
\text { Correlation }\end{array}$ & $.838^{* *}$ & $.791^{* *}$ & $.817^{* *}$ & 1 \\
\hline & Sig. (2-tailed) & .000 & .000 & .000 & \\
\hline & $\mathrm{N}$ & 193 & 193 & 193 & 193 \\
\hline
\end{tabular}

**. Correlation is significant at the 0.01 level (2-tailed).

Additionally, regression analysis was used to test the developed hypotheses. Simple Regression was used in order to test Hypothesis 1 which assumes that decision-making empowerment has a significant impact on women entrepreneurship development. As shown in Table 9, the results reveal that the $\mathrm{R}^{2}$ was 0.702 , which indicates that decision-making empowerment as the whole independent variable can explain $70 \%$ of the variance of women entrepreneurship. In addition, the F statistic is substantiated at the $1 \%$ significance level $(\mathrm{F}=449.765, \mathrm{Sig}=.000)$, 
implying that the null hypothesis can be rejected. Based on coefficients values provided, decision-making empowerment contributes to $58.6 \%$ of women entrepreneurship. In summary, decision-making empowerment has a significant impact on women entrepreneurship and hypothesis 1 is supported.

Table 9 Simple Regression Analysis Result: Decision-Making Empowerment as one variable

\begin{tabular}{llllllll}
\hline \multirow{2}{*}{ Model (1) } & \multicolumn{2}{l}{$\begin{array}{l}\text { Unstandardized } \\
\text { Coefficients }\end{array}$} & $\begin{array}{l}\text { Standardized } \\
\text { Coefficients }\end{array}$ & $\mathbf{t}$ & Sig. & F & R Square \\
\cline { 2 - 6 } & $\mathrm{B}$ & Std. Error & Beta & & & & \\
(Constant) & 2.224 & .094 & & 23.564 & .000 & & \\
Decision-Making & .586 & .028 & .838 & 21.208 & .000 & 449.765 & .702 \\
Empowerment & & & & & & \\
\hline
\end{tabular}

a. Dependent Variable: Women Entrepreneurship

b. Predictors: Decision-Making Empowerment

Furthermore, Multiple Regression analysis was used for the purpose of testing the two sub-hypotheses; H1a and $\mathrm{H} 1 \mathrm{~b}$, which are related to examining the impact of economic decision making, and household decision making dimensions on women entrepreneurship. Table 10 indicates that $\mathrm{R}$ Square $=0.704$ which means that economic decision making and household decision making dimensions are explaining $70.4 \%$ of the variance of women entrepreneurship.

Table 10 Multiple Regression Analysis, Model Summary

\begin{tabular}{lllll}
\hline Model & $\mathbf{R}$ & R Square & Adjusted R Square & Std. Error of the Estimate \\
\hline 1 & $.839^{\mathrm{a}}$ & .704 & .701 & .31120 \\
\hline \multicolumn{4}{l}{ a. Predictors: (Constant), Household_decisionmaking, Economic_decisionmaking }
\end{tabular}

In addition, Table 11 shows the result of ANOVA test which indicates that $\mathrm{F}$ statistic is substantiated at the $1 \%$ significance level $(\mathrm{F}=225.830$; Sig. $=0.000)$, implying that the null hypotheses can be rejected.

Table 11 ANOVA Test

\begin{tabular}{lllllll}
\hline Model & & Sum of Squares & df & Mean Square & F & Sig. \\
\hline \multirow{4}{*}{1} & Regression & 43.740 & 2 & 21.870 & 225.830 & $.000^{\mathrm{b}}$ \\
& Residual & 18.400 & 190 & .097 & & \\
& Total & 62.140 & 192 & & & \\
\hline
\end{tabular}

a. Dependent Variable: WomenEntrepreneurship

b. Predictors: (Constant), Household_decisionmaking, Economic_decisionmaking

The Coefficients results in Table 12 shows that economic decision making contributes significantly $(\beta=0.240, p$ $=0.000$ ) to $24 \%$ of Women Entrepreneurship, meaning that economic decision-making empowerment has a significant impact on women entrepreneurship, and this supports H1a. In addition, household decision making contributes significantly $(\beta=0.346, p=0.000)$ to $34.6 \%$ of Women Entrepreneurship, indicating that Household decision-making empowerment has a significant impact on women entrepreneurship, which supports H1b.

Table 12 Coefficients Results

\begin{tabular}{|c|c|c|c|c|c|c|}
\hline \multirow[b]{2}{*}{ Model } & & \multicolumn{2}{|c|}{$\begin{array}{l}\text { Unstandardized } \\
\text { Coefficients }\end{array}$} & \multirow{2}{*}{$\begin{array}{l}\text { Standardized } \\
\text { Coefficients } \\
\text { Beta } \\
\end{array}$} & \multirow[t]{2}{*}{$\mathbf{t}$} & \multirow[t]{2}{*}{ Sig. } \\
\hline & & B & Std. Error & & & \\
\hline 1 & (Constant) & 2.228 & .094 & & 23.605 & .000 \\
\hline & Economic_decisionmaking & .240 & .050 & .354 & 4.836 & .000 \\
\hline & Household_decisionmaking & .346 & .049 & .519 & 7.098 & .000 \\
\hline
\end{tabular}

a. Dependent Variable: WomenEntrepreneurship 


\section{Discussion and Conclusion}

According to the findings, decision-making empowerment has a significant impact on women entrepreneurship development, which confirms Hypothesis H1. This result is in line with the result of the study of Nussbaum (2001), who concluded that the concept of women decision-making empowerment appears and becomes one of crucial development issues and it affects women entrepreneurship significantly. Women empowerment refers to increasing and improving the social, economic, political and legal strength of the women, to ensure equal-right to women, and to make them confident enough to claim their rights. Moreover, Dwivedi and Dwivedi (2011) confirmed the contribution of female-entrepreneurs to the economic development. Mathew and Panchanatham (2011) emphasized that the growth of the family and the country in general can be attributed to the growth of women.

According to the results of the Multiple Regression Analysis, economic decision-making empowerment has a significant impact on women entrepreneurship, which supports Hypothesis H1a. This result is inline with the study of Rocca et al. (2009) who found that women can be empowered through vocational training which can contribute to the female entrepreneurship and social transformation. Sontheimer (1991) asserted on women's participation globally, regionally and locally which has a significant role in the process of sustainable development

In addition, results show reveal that household decision-making empowerment has a significant impact on women entrepreneurship development, which supports Hypothesis H1b. This result is consistent with Kabir and Huo (2011) who found that the contribution of women in household earning is supposed to pave their way for decision making in household affairs and empower them significantly. Women's contribution to increasing income paved the way for their respected position in household decision-making, which is positively reflected in the development of women's entrepreneurship. According to Selwin and Harris (2014), women participation in decisions related to family matters such as freedom to visit places, decisions regarding children, or spending money will make women feel empowered. Women with greater decision-making power and self-reliance in various household activities may be more empowered compared to women without these traits.

It can be concluded that empowering women appears to be one of the important factors for developing women's entrepreneurship in particular, which in turn will help reduce poverty as well as achieve economic growth. Preventing women from participating in economic or family decision-making is one of the reasons for their failure in entrepreneurship in general.

Furthermore, these findings will aid women make better decisions by supporting them in achieving their business goals. This can enhance the operational and strategic decision making, accordingly creating a competitive advantage for the business.

\section{Recommendations}

The results of the study confirm the impact of decision-making empowerment with its two dimensions; economic decision-making empowerment, and household decision-making empowerment on women entrepreneurship development. Accordingly, recommendations were provided as follows:

- Women in Yemen should be aware of the importance of the economic and household decision-making empowerment, which play a vital role in developing their entrepreneurship.

- The Yemeni government should encourage women entrepreneurs, by developing policies and strategies that support entrepreneurship development.

- The Yemeni government should make efforts to empower women economically by facilitating the establishment of their businesses.

- Raising societal awareness of women's participation in decision-making

- Parents and husbands should encourage women and girls to be able to make decisions because it will develop their abilities to manage their projects in the future.

- Women entrepreneurs should pay attention to developing and educating themselves in everything related to their economic empowerment.

- Women and girls need family support in the first place and governmental support in the second place.

- The government should be aware of the importance of empowering women and helping them to succeed in their projects, which are a mainstay of the national economy. 


\section{Future Research}

For the future researches, collecting more samples may lead to more accurate results and it's also a good idea to make a comparative study including the whole business and generalizes one model for the Yemeni's market. Generalizing the model to a cross-industry and cross-country might be a good idea as well.

Expanding the geographic scope of the research to include other across different types of demographics could show different concerns because of different business conditions. In addition, surveying a larger sample would allow for more detailed analysis. Another related effort would be to break down participants into various business activities.

\section{References}

Abdo, N., \& Kerbage, C. (2012). Women's entrepreneurship development initiatives in Lebanon: microachievements and macro-gaps. Gender \& Development, $20(1), 67$.

Afrin, S., Islam, N., \& Ahmed, S. (2008). A multivariate model of micro credit and rural women entrepreneurship development in Bangladesh. Sharmina Afrin, Nazrul Islam \& Shahid Uddin Ahmed (2008), A Multivariate Model of Micro Credit and Rural Women Entrepreneurship Development in Bangladesh, International Journal of Business and Management, 3(8), 169-185.

Andrews, E., Barbera, N., Mickle, M., \& Novik, H. (2013). Prospects for women's economic empowerment. Institute for Global and International Studies. The George Washington University.

Ardichvili, A., Cardozo, R., \& Ray, S. (2003). A theory of entrepreneurial opportunity identification and development. Journal of Business venturing, 18(1), 105-123.

Ariffin, A. S., Baqutayan, S. M. S., \& Mahdzir, A. M. (2020). Enhancing women entrepreneurship development framework: Policy \& institution gap and challenges in the case of Malaysia. Journal of Science, Technology and Innovation Policy, 6(2), 22-33.

Bekefi, T., Epstein, M. J., \& Yuthas, K. (2008). Creating growth: Using opportunity risk management effectively. Journal of Accountancy, 205(6), 72.

Belenky, M. F., Clinchy, B. M., Goldberger, N. R., \& Tarule, J. M. (1986). Women's ways of knowing: The development of self, voice, and mind (Vol. 15). New York: Basic books.

Boserup, E., \& Kanji, N. (2007). Woman's role in economic development. Earthscan and mind. Basic books.

Boyd, N. G., \& Vozikis, G. S. (1994). The influence of self-efficacy on the development of entrepreneurial intentions and actions. Entrepreneurship theory and practice, 18, 63-63.

Burns, P. (2010). Entrepreneurship and Small Business: Start-up. Growth and Maturity. Palgrave Macmillan.

Cheston, S., \& Kuhn, L. (2002). Empowering women through microfinance. Draft, Opportunity International, 64, $1-64$.

Koh, H. C. (1996). Testing hypotheses of entrepreneurial characteristics: A study of Hong Kong. Journal of managerial Psychology, 11(3), 12-25.

Cornwall, A. (2016). Women's Empowerment: What Works?. Journal of International Development, 28(3), 342359.

Curtis, R. F. (1986). Household and family in theory on inequality. American sociological review, 168-183.

Davis, S. M. (2002). Social entrepreneurship: Towards an entrepreneurial culture for social and economic development. Available at SSRN 978868.

Duru, A. N. (2011). Understanding Men's Interference in Women's Empowerment and Non-Governmental Organizations (NGOs) in Nigeria: A Gender Comparison (Doctoral dissertation, Howard University).

Dwivedi, A. K., \& Dwivedi, N. (2011). Women-empowerment through women entrepreneurship (A study of Faizabad zone of Uttar-Pradesh). Available at SSRN 1886250. 
Fülöp, J. (2005). Introduction to decision making methods. In BDEI-3 workshop, Washington (pp. 1-15).

Fulp, C. F. (2014). Ghanaian Voices: Examining the Causal Relationship between Entrepreneurship and Women's Empowerment in Ghana (Doctoral dissertation).

Goetz, A. M., \& Sen Gupta, R. (1994). Who takes the credit? Gender, power and control over loan use in rural credit programmes in Bangladesh. Anne Marie Goetz Fellow, Institute of Development Studies, University of Sussex Falmer, Brighton, BN1 9RE.

Graflund, F. (2013). THE IMPACT OF MICROCREDIT ON WOMEN'S EMPOWERMENTA CASE STUDY OF MICROCREDIT IN THE TANGAIL DISTRICT. BANGLADESH, Department of Economics at the University of Lund, Minor Field Study Series, (225).

Grasmuck, S., \& Espinal, R. (2000). Market success or female autonomy? Income, ideology, and empowerment among microentrepreneurs in the Dominican Republic. Gender \& society, 14(2), 231-255.

Goheer, N. A. (2003). Women entrepreneurs in Pakistan (pp. 1-43). Geneva: International Labour Organization.

Hagar, H. (2015). Business opportunity identification for entrepreneur in Finland.

Hammond, J. S., Keeney, R. L., \& Raiffa, H. (2015). Smart choices: A practical guide to making better decisions. Harvard Business Review Press.

Healy, P. M., \& Palepu, K. G. (2001). Information asymmetry, corporate disclosure, and the capital markets: A review of the empirical disclosure literature. Journal of accounting and economics, 31(1), 405-440.

Jitha, T. J. (2013). Mediating Production, Re-powering Patriarchy: The Case of Micro Credit. Indian Journal of Gender Studies, 20(2), 253-278.

Kabeer, N. (1999). Resources, agency, achievements: Reflections on the measurement of women's empowerment. Development and change, 30(3), 435-464.

Kabeer, N. (2005). Gender equality and women's empowerment: A critical analysis of the third millennium development goal 1. Gender \& Development, 13(1), 13-24.

Kabir, M. S., \& Huo, X. (2011). Advancement of rural poor women through small entrepreneurship development: The case of Bangladesh. International journal of business and management, 6(9), 134.

Katz, J., \& Gartner, W. B. (1988). Properties of emerging organizations. Academy of management review, 13(3), 429-441.

Kennedy, P. (2002). Learning cultures and learning styles: Myth-understandings about adult (Hong Kong) Chinese learners. International journal of lifelong education, 21(5), 430-445.

Kishor, S., \& Subaiya, L. (2005, July). Household decision making as empowerment: A methodological view. In presentation at the 2005 Meeting of the International Union for the Scientific Study of Population (IUSSP), Tours, France.

Krejcie, R. V., \& Morgan, D. W. (1970). Determining sample size for research activities. Educational and psychological measurement, 30(3), 607-610.

Li, Y., Chen, H., Liu, Y., \& Peng, M. W. (2014). Managerial ties, organizational learning, and opportunity capture: A social capital perspective. Asia Pacific Journal of Management, 31(1), 271-291.

Low, M. B., \& MacMillan, I. C. (1988). Entrepreneurship: Past research and future challenges. Journal of management, 14(2), 139-161.

Lumpkin, G. T., \& Dess, G. G. (1996). Clarifying the entrepreneurial orientation construct and linking it to performance. Academy of management Review, 21(1), 135-172.

Mathew, R. V., \& Panchanatham, N. (2011). An exploratory study on the work-life balance of women entrepreneurs in South India. Asian academy of management journal, 16(2), 77-105. 
McKee, K. (1989). Microlevel strategies for supporting livelihoods, employment, and income generation of poor women in the third world: The challenge of significance. World Development, 17(7), 993-1006.

Moghadam, V. M., \& Senftova, L. (2005). Measuring women's empowerment: participation and rights in civil, political, social, economic, and cultural domains. International Social Science Journal, 57(184), 389412.

Moore, M. G. (1973). Toward a theory of independent learning and teaching. The Journal of Higher Education, 44(9), 661-679.

Moses, C., \& Amalu, R. (2010). Entrepreneurial motivations as determinants of women entrepreneurship challenges. Petroleum-Gas University of Ploiesti Bulletin, (2), 67-77.

Nessa, T., Ali, J., \& Abdul-Hakim, R. (2012). The impact of microcredit program on women empowerment: Evidence from Bangladesh. OIDA International Journal of Sustainable Development, 3(9), 11-20.

Nmark, F. L. (1993). Women, leadership, and empowerment. Psychology of women quarterly, 17(3), 343-356.

Nussbaum, M. C. (2001). Women and human development: The capabilities approach (No. 3). Cambridge University Press.

Pandey, S , Singh, M.(2008). Women Empowerment and Personal Values as Predictors of Reproductive Health, Journal of the Indian Academy of Applied Psychology, 34(2), 309-316.

Pitt, M. M., Khandker, S. R., \& Cartwright, J. (2006). Empowering women with micro finance: Evidence from Bangladesh. Economic Development and Cultural Change, 54(4), 791-831.

Rani, D. L. (1996). Women entrepreneurs. APH Publishing.

Robinson, J. P., Shaver, P. R., \& Wrightsman, L. S. (Eds.). (2013). Measures of personality and social psychological attitudes: Measures of social psychological attitudes (Vol. 1). Academic Press.

Rocca, C. H., Rathod, S., Falle, T., Pande, R. P., \& Krishnan, S. (2009). Challenging assumptions about women's empowerment: social and economic resources and domestic violence among young married women in urban South India. International journal of epidemiology, 38(2), 577-585.

Rowlands, J. (1997). Questioning empowerment: Working with women in Honduras. Oxfam.

Saaty, T. L. (1990). Decision making for leaders: the analytic hierarchy process for decisions in a complex world. RWS publications.

Sabri, N. (2015). From invisibility to visibility: Female entrepreneurship in Afghanistan. University of Oregon.

Selwin, S., \& Harris, S. B. (2014). Do women still have a medieval mindset towards themselves? A study on the impact of decision making index in empowering woman entrepreneurs. TSM Business Review, 2(1), 81.

Sen, G., \& Batliwala, S. (2000). Empowering women for reproductive rights. na.

SFD (2019), Annual archive of loan portfolio, The Small \& Micro Enterprise Development (SMED) Unit, Accessed in July 2021, https://smed.sfd-yemen.org/index.php/ar/2018-09-06-09-22-20/324-ar112019

Sharma, M. P. (2015). Women Entrepreneurs: Challenges \& Opportunities. Retrieved, 3(21), 2016.

Singh, S., Simpson, R., Mordi, C., \& Okafor, C. (2011). Motivation to become an entrepreneur: a study of Nigerian women's decisions. African Journal of Economic and Management Studies, 2(2), 202-219.

Smeaton, D., Ray, K., \& Knight, G. (2015). Costs and benefits to business of adopting work life balance working practices: A literature review. UK Department for Business, Innovation and Skills, London. http://www.psi.org.

Sontheimer, S. (Ed.). (1991). Women and the Environment: A reader: Crisis and Development in the Third World. Earthscan. 
Subbiah, S. (2019). Impact of Micro Finance on Decision Making Empowerment of SHGs Women Members in Tirunelveli District.

Swift, C., \& Levin, G. (1987). Empowerment: An emerging mental health technology. The Journal of Primary Prevention, 8(1), 71-94.

Wiklander, J. (2010). Determinants of women's empowerment in rural India: an intra-household study.

Women's News Agency. (2013). Interview with Dr. Fawzia Nasher: The Yemeni Business women's Council helps in developing the capabilities of women. Retrieved in 2017, from http://iknowpolitics.org/ar/knowledgelibrary/interviews/

\section{Copyrights}

Copyright for this article is retained by the author(s), with first publication rights granted to the journal. This is an open-access article distributed under the terms and conditions of the Creative Commons Attribution license (https://creativecommons.org/licenses/by-sa/4.0/). 